\title{
Effect of Financial Leverage on Firm Value: Evidence From Selected Firms Quoted on the Nigerian Stock Exchange
}

\author{
Umar Abbas Ibrahim, $\mathrm{PhD}$ * AbdulQudus Isiaka \\ Department of Business Administration, Nile University of Nigeria
}

\begin{abstract}
This study examined the effect of financial leverage on firm value with evidence from a sample of selected companies quoted on the Nigerian Stock Exchange. The study adopts a panel data analysis using secondary data obtained from the financial statements of the selected companies over the period 2014-2018. The sample of 18 firms studied was selected through the convenient sampling technique. The level of financial leverage was denominated by long term debt to equity ratio. This work is the first Nigerian study to utilize the Tobin's q ratio as a proxy of firm value. Other variables proven in literature to be of importance when considering firm value such as Total Asset, Return on Asset and the Number of years for which the firm has been in operation, were utilized as control variables in presenting the Tobin's Q model of firm valuation. Data obtained were analyzed by EVIEWS to determine the extent of the causal and correlational relationships between the dependent variable and the regressors. The study determined the degree of causality using the Pooled Ordinary Least Squares (POLS), Random Effect Panel Data Model(REM) and Fixed Effect Panel Model(FEM) estimation techniques. The correlation coefficients were estimated using the pairwise correlation matrix to determine the extent to which financial leverage can predict firm value In line with the findings of Akani \& Kenn-Ndubuisi (2017); the regression results showed that financial leverage has a significantly negative effect on firm value while the result of the pairwise correlation showed that there is no significant linear relationship between leverage and firm value. The Management of these companies were advised to take less long term debts and instead such firms should consider issuing more equity to reduce the level of financial leverage to thereby attain the optimal capital structure. Financial leverage has proven to be a weak predictor of firm value; hence the management should not rely on the levels of financial leverage to predict future firm value. Future studies may consider the use of a larger sample and a random sample selection method which will group the firms based on their level of capitalization into mid, low and high-capitalization companies so which will help to ascertain the average optimal capital structure for each of the three classes. Finally, future studies can consider a longer time span.
\end{abstract}

Keywords: Firm value, Tobin's q, Financial Leverage, REM

JEL Classification: G11; G32; M21

DOI: $10.7176 / \mathrm{EJBM} / 12-3-16$

Publication date: January $31^{\text {st }} 2020$

\section{Introduction}

The growing levels of corporate debt profiles and issue of corporate debt instruments has made it an imperative to understand what the key drivers of a geared capital structure are, as well as its implications for the financial performance and value of such firms. The theoretical position on the effect of financial leverage and capital structure on the value of firms is well known and has been discussed extensively by researchers like Arosa, Richie and Schumann (2014); Lee, Su, \& Lin, (2012). However, as Eldomiaty, Choi and Cheng (2007) noted that capital markets in developing economies are largely inefficient when compared to those of advanced economies because of the information asymmetry. In other words, it is not likely that inferences drawn from data obtained from advanced economies would be applicable to a developing economy such as Nigeria.

Other structural differences which have been identified include multiple taxation, volatile depositor base, Limited market capitalization, fewness of non-governmental long debt market, regulatory inadequacy, and perhaps the most relevant to this study being the lack of fiscal space or tax shield (Oteh, 2010). In practice, when a firm embarks on a financing decision, there are basically two alternatives available to the management to choose from namely debt and equity.

Whereas, Debt financing entails short-term payment obligations, the issue of long term debt instruments such as bonds in the capital market and finding credit facilities in the loan market. Equity financing basically involves the raising of capital through the issue of a company's stocks in the capital market. Equity financing may also take the form of reinvested earnings whereby past profits which have been a part of shareholders' fund is purposely converted into share capital. Usually, firms combine both forms of financing- debt and equity in their capital structure and although many firms are levered, studies have shown that short term loans like trade payables account more for their leveraged capital structure and not long term debts which are not easy to obtain (Salawu, 2009).

In order to further ensure that companies in the real sector gain access to long term debt financing at a reasonable rate the central bank recently made a standing deposit facility policy which restricts commercial banks' daily investment in government securities to a maximum of N2billion (CBN, 2019). The Apex bank had 
recognized the importance of the intermediary role of the Money Deposit Banks in providing funding for businesses, a role which has been eroded by the riskless profiteering objective of banks who prefer to invest in government securities which they consider to be risk-free. The effect has been very high cost of funds, and a capital structure which is perennially tilted towards equity-funding.

However, the low level of debt financing in Nigeria and many emerging economies is due to the situation of key macro-economic indicators such as unemployment, government expenditure, and inflation rate which altogether create a vicious cycle that appears to be self-perpuating. According to Mishkin (2007), governments in a bid to close the output gap and thereby achieve full employment often resort to expansionary monetary policies which often increase the lending rate and crowd out funds from the private sector by way of high lending rates. Investment banks being economic agents capitalize on such high rates to earn rentals but the real sector is left hurt because their earnings are often eroded by high debt servicing and repayment cost.

Modigliani and Miller (1958) had initially proposed the Capital structure Irrelevance theory which is the first of two theories attributable to the two researchers, wherein they alluded to the insignificance of financial leverage in assessing the profitability of the firm. Later on, they took into consideration the effect of the corporate tax shield which accrues to debt and thus suggested that firms that diversify their capital structure to include as much debt as possible would tend to maximize their value (Modigliani and Miller, 1967).

\subsection{Statement of the Research Problem}

Several researchers like Gill and Obradovich (2013), Pandey and Sahu (2017) have thus argued that firms should take advantage of the net effect of the tax saving as no significant financial risk arises on account of a more leveraged capital structure. However, a number of other researchers have argued that the dampening effect of higher financial risk especially in the face of information asymmetry diminishes investors' confidence and may increase the cost of funds. For this reason, Khan (2012) and Abor and Bokpin (2010) opined that firms with larger debt profile are considered to be more volatile investment and as such are not able to borrow as much others.

The levels of debts in quoted companies have continued to rise considerably, and as Salawu (2009) stated that debts account for up to $60 \%$ of the capital of Nigerian firms, this suggests a trend in capital structure of firms which necessitates a review. Especially in order to determine the impact of such debt levels on the performance of firms in an emerging economy as the Nigerian economy. The objective of management is to optimize Shareholders' wealth, although firm value has several proxies such as Return on Investment, Return on Equity and Market Value of the Firm's Shares each of which sometimes responds differently to variations in firms' capital structure.

Demirguc-Kunt and Maksimovic (1999) observed that marked differences in the structure of developing and emerging economies have made comparisons of research works from the two spheres not meaningful. For example, stock markets in underdeveloped economies are challenged by the inherent weaknesses in their institutions and the absence of a comprehensive risk management systems (Salawu 2009). Moreso, developing countries have much smaller and less sophisticated debt instrument market, so firms have traditionally relied on long term credit from the banks to fund their long term operational and investment needs. Inflationary trends and high level of economic risk has also forced a large majority of deposit money banks in the country to only advance loans at very prohibitive rates.

The common supposition which underpins many existing works regarding debt financing and firm value is the need for some element of debt financing (Toraman, Kihc \& Reis, 2013). However, most existing research works have failed to address the omitted variable bias which arises from the inadequacy of the drivers utilized in modelling firm value (Kyereboah-Coleman, 2007). Abor and Biekpe (2007). Also, most existing research studies of Nigerian firms such as Kenn-Ndubuisi and Nweke (2019) and Isola and Akanni (2015) have considered only the current performance of firms using perform indices such as ROE and ROI as against Tobin's q, which is considered a better measure of firm value. The Tobin's Q ratio comprises of two variables namely market value of the firm and the replacement cost of the assets of the firm (Fisher and McGowan, 1983)

Recent studies carried out to ascertain the impact of leverage on firm value have either utilized samples of firms in only specific sectors as in the case Abdul \& Badmus (2017) or selected firms without covering all the market segments as in the studies of Dare \& Sola (2010) which sampled firms in the petroleum industry; Akamelu, Iyidiobi \& Ezejiofor (2017) which investigated only the food production firms using six quoted firms; while Thaddeus and Chigbu (2012) appraised six financial institutions. Hence, there is a need for extending the study to cover all the industries on the Nigerian Bourse.

Similarly, this study is the first indigenous work to use the Tobin's ratio as an index of firm value of Nigerian companies. Existing works have used Return on Assets ROA, Return on Equity ROE, as well as Earnings Before Interest and Tax (EBIT). However, according to Fisher et al. (1983) these measures are not surrogates of firm value, the best alternative utilized so far has been the market capitalization which although has its merits assumes informational market efficiency which may not apply in developing economies.

This work thus explores the causal and correlational relationship between financial leverage and firm value, in the specific case of firms quoted on the Nigerian Stock Exchange. With a sample of 18 companies drawn from 
various industries over the five-year period between 2014 and 2018, this study adopted the trade-off theory as the theoretical framework and the Pooled Ordinary Least Squares Model (POLS), the Random Effect Panel Data Model(REM) and the Fixed Effects Panel Data Model(FEM) as alternative empirical models for panel data analysis.

\subsection{Statement of Research Questions and Hypotheses}

Using the three major different Panel data regression models this works will address the following research questions: to what extent does financial leverage affect firm value? and is there a significant linear relationship between financial leverage and firm value?

Hypothesis One $\left(\mathrm{Ho}_{1}\right)$ : Financial leverage has no significant effect on firm value

Hypothesis Two $\left(\mathrm{Ho}_{2}\right)$ : There is no significant linear relationship between financial leverage and Tobin 's $Q$

The findings from this study will be particularly useful in determining the applicability of the Trade- off theory (as an alternative to the Modigliani and miller theory) in the case of firms operating within emerging economies such as the Nigerian economy, by providing empirical evidence to prove its postulations. Secondly, the outcomes of this study will help firms quoted on the Nigerian stock exchange to ascertain the important factors which affect their firm value.

The rest of the study would be divided into the following sections: Literature review of the relevant concepts such as Debt, Equity, Leverage, Market Value and Asset. Also in this section, findings from recent related studies will be reviewed. The third section discusses the methodology adopted for the purpose of the study. The fourth section presents the panel data regression results and analysis whilst the fifth section contains the summary of findings made recommendations for the management of the firms concerned as well as for further studies.

\section{Literature Review}

2.1 Conceptual and Theoretical Framework

Financial Leverage refers to the degree to which a firm's capital structure comprises more of long term debt as against equity.

$$
\text { Financial Leverage }=\frac{\text { Long term Debt }}{\text { Total Equity }}
$$

The term leverage describes the ratio of long term debt to total equity and it is alternatively stated as the ratio of long term debt to total capital. This concept as well as it is effect on the firm has been the focus of theories such as the Capital Structure Irrelevance theory of Modigliani and Miller (1958), Modigliani and Miller (1963), the agency theory of Jensen and Meckling (1979), the trade-off theory of Mayer (1984). Modigliani and Miller (1967) had postulated that a levered firm was not only taking advantage of tax free debt to lower cost but that since debts are by virtue of arbitrage channels risk-free, firms can take advantage of the tax shield and still not have to bother about their finance risks.

Myers (1977) however noted that existing shareholders of firms with high levels of debt will only be motivated to invest more if and only if expected return on investment is greater than or as much as the returns long term creditor are promised. Otherwise Shareholders refuse to make more investment which may lead to situation he termed as underinvestment. This expectation of shareholders is explained by the fact that a more leveraged firm tends to expose the direct owners or shareholders to greater risk and as such justifies higher returns for the owners.

Debt refer to funds obtained by corporate entities for the purpose of executing a particular project or running the business. Debts are contractual agreements which give the creditor a right to be paid the principal sum and an agreed percentage of the principal as interest before the company declares profit and pays dividend. Also, holders of the company's debt securities of the company, have a primary claim on the company's assets in the event of bankruptcy or insolvency.

Schmidt and Tyrell (2002) noted that debts many times are either sourced from the capital market or the banks, such that firms which obtain more of their debt through the issue of bonds in the capital market are referred to as capital market dominated and where the reverse obtains they are referred to as bank dominated.

Loans are obtained from banks at a negotiated rate of interest and pre-agreed repayments scheme while a bond creates a legal commitment for the entity borrowing to pay regularly a coupon on the principal sum and, in most cases, to return the principal when the bond reaches maturity. Importantly whereas bonds are transferrable in a secondary market through the sale of such debt instruments before maturity, loans can only be discounted or converted before the end of the tenure (SEC, 2015).

The Long term to debt ratio is one of the several gearing ratios which determine the leverage of an entity by comparing the debt obligations of the company (which are meant to finance capital projects and are expected to endure for more than a period) with the capital contributed by equity holders. The ratio reflects the portion of the business that is funded by borrowed funds as against wholly-owned funds. Mayer (1984) opined that as the D/E ratio rises (debt outweighs equity in a company's capital structure) more debts will only bring about a loss in the firm value. 
Tobin and Brainard (1968) introduced the Tobin's Q and explained it as the ratio of the company's market value to the replacement cost of its asset.

$$
Q=\frac{\text { Market Value of the Shares of firm }}{\text { Replacement Cost of Firm's Assets }}
$$

Fisher and McGowan (1983) while comparing Tobin's Q with accounting rate of return as a measure of firm value stated that by combining stock market data with accounting data, Tobin's Q produces a more accurate measure of firm rent. Tobin's q provides the framework for this construct. Relying on capital markets to value rents substantially eliminates most of the shortcomings inherent in accounting profit rates. Additionally, Ganguli and Agrawal (2009) stated that the Tobin's Q model builds in inherent finance risk, resulting in a more forward looking valuation of the firm. Additionally, there has been a debate as to how best to state the firm value model with different authors coming up with a variety of variables which although related but are essentially not the same. This implies that there is a need to determine the most reliable and robust model of firm value. In order to ascertain the degree of causal relationship between debt level and firm value. It was in order to cater for this that a few researchers like Abor and Bokpin (2010) adopted the fixed effects or dummy variables to provide for differences over time and companies- a reliable empirical model which accounts for heterogeneity or differences between companies and across time.

The market value of the shares of a firm refers to the contemporaneous market capitalization of the firm. In other words, it is the product of the outstanding shares of the firm and the current share price in the stock market. The Market value of shares gives the management as well as intending lenders an idea of the prospects of the firm. This refers to the book value of the assets of a firm alternatively it is the fair value of the firm's tangible assets. This provides an idea of the firm's actual value. Generally, given two firms with a similar market capitalization the firms whose assets cost more to replace would be said to have a lower firm value.

Basically, it is expected that higher leverage should bring about higher firm value because of the fact that debt is not tax deductible, which increase the net income or future streams of income of the firm. However, because this future stream of income must be discounted by the risk adjusted cost of fund, the risk of default will create a counter effect on the gains in terms of reduced present value of future streams of earning and in effect market value. Franks \& Pringle (1982) however opined that the value of firms does actually depend on not just the level of debt of the firm but it also takes the debt capacity of the firm in question into consideration.

To optimize firm value therefore, some researchers like Modigliani and Miller (1969) have simply prescribed a continuous increase in firm leverage so long as the firm's total cost of financing debts (which includes debtissuing costs, bankruptcy costs, agency costs), is less than the total benefits (such as interests tax shields, lower agency cost of equity). However, under the traditional theory of capital structure paradigm the relationship between leverage and firm value is depicted as a concave shape having an optimal capital structure at the point where the gradient of the function is zero. In this way, other researchers like Robicheck and Meyer (1966), Hamada (1969) and Schall (1972) recommended the use of an equi-marginal principle which suggests that firm value continues to rise so long as marginal gains from leverage is higher than marginal expected loss from the default costs. When marginal gain becomes smaller than the marginal cost the firm value declines (Kim, 1978).

Hence, what appears to be more plausible is that the relationship between financial leverage and Tobin's Q is a random one where changes are not exactly deterministic. However, a number of drivers have been considered to be the chief determinants they are namely: the size of the firm, the number of years for which it has been in existence, the level of profitability of the firm. Some researchers have also alluded to the tax regime, as well as the economy and the level of information symmetry capital market in which the firm operates.

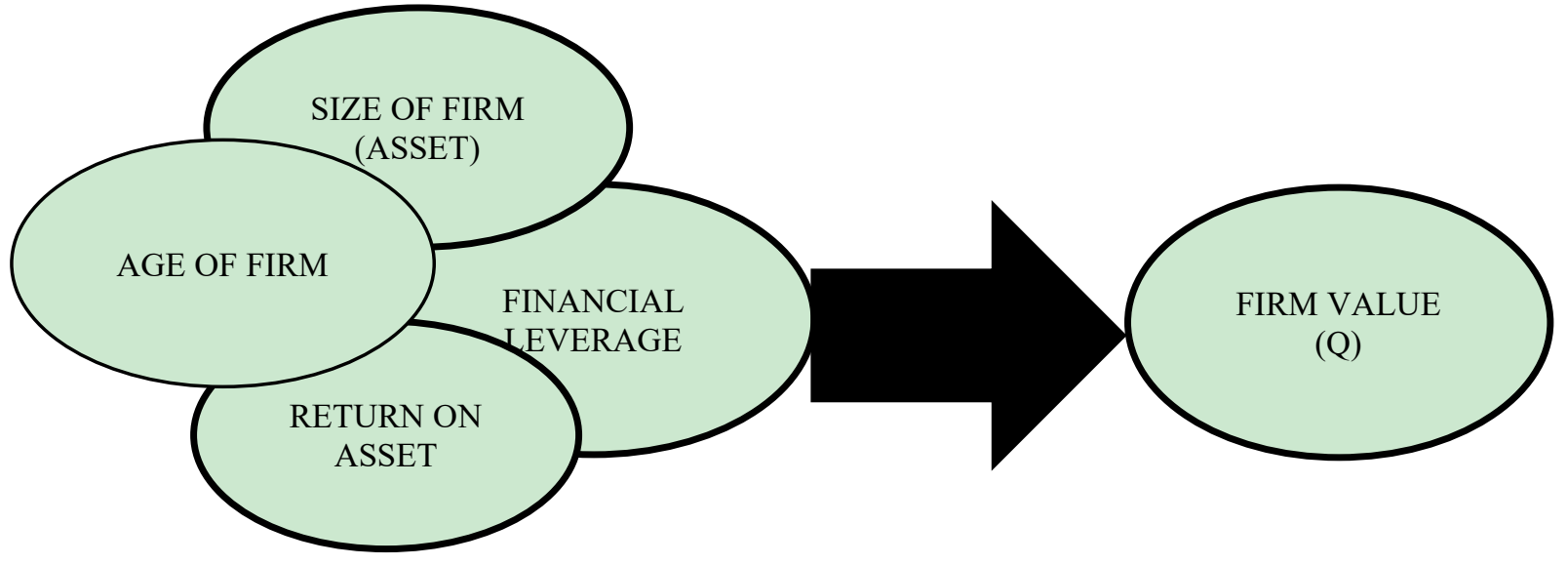

Figure 1: Conceptual Framework of the effect of financial leverage and other dependent variables on firm value. This study is based on the Trade-off theory of Capital structure propounded Mayer (1984) by which states 
that an all equity firm has zero default risk and a constant value but soon as debt is introduced into the capital structure there is higher default risk but higher value. However, the sustained increase in firm value will depend more and more critically on the contemporaneous level of financial leverage. In order words as the level of debt to equity rises firm value reaches its maxima and subsequently more debt leads to higher default risk and loss of firm value. This theory is particularly relevant to this study because it makes no perfect market assumption and actually relate firm capital structure.

Trade-off models have been extensively discussed in the capital structure literature. There have in fact been variants of the trade-off theory each modifying the components of cost of debt and benefits derivable thereby. For example, Scott (1976) predicted that firms will seek to balance the benefits and the costs of debt where the tax advantage and costs which include the risk of default which translates to a much higher finance cost. Hart and Moore (1995) on the other hand, state that firms use the benefits of reduced chances of inadequate free cash flow, to counteract the effect of costs arising from asset substitution problems.

\subsection{Empirical Review}

Literature is replete with several studies on the effect of financial leverage on firm performance and value. In fact, some authors went as far as to appraise the issue of Optimal Capital Structure (OCS) and have arrived at varied conclusions. While authors like Ferri \& Jones (1979); Kester, (1986); Rajan \& Zingales (1995) made attempts to prescribe certain optimum capital structure, some other researchers maintain that there is no such thing as an equilibrium level of debt or capital structure and that the decision regarding debt financing are based purely on the availability and cost of funds (Arosa et al, 2014). However, with regard to the more fundamental issue of the nature of causal relationship between financial leverage and firm value, the plethora of existing works reviewed have been grouped into the three following categories.

Gill and Obradovich (2013) examined the impact of financial leverage and corporate governance on the firm value of American companies. Using a co-relational and causal research design to study a sample of 333 firms listed on New York Stock Exchange (NYSE) over a period of 3 years from 2009-2011. The major finding of the study was that financial leverage, firm size, return on assets, and insider holdings positively impacted on the value of American firms. Although, Gill et al. (2012) followed the models of previous works like Kyereboah-Coleman (2007) and Abor and Biekpe (2007), the predictive strength of the model is very low $\mathrm{R}^{2}=0.238$; Adjusted $\mathrm{R}^{2}=$ 0.219 indicating a possible omission of variables

To address this problem, Pandey and Sahu (2017) while investigating the effect of capital structure on the performance of manufacturing companies quoted on the Bombay Stock Exchange (BSE) of India over the period of 2009-2016; carried out the Hausman Test to check for omitted variable bias and systematical differences in the coefficients. The Fixed Effect Model which is also known as the Least Squares Dummy Variable Model was later utilized to estimate the parameters of the variables and the study found that capital structure had a significantly negative effect on the performance of the selected firms. The study proposed that the firms' accounting performance as the function of almost all the variables of capital and ownership structure used in the study.

Abubakar (2016) examined the impact of leverage (denominate by TDER) on firms' performance (denominated by ROE) by studying 66 non-financial firms quoted on the Nigerian Stock Exchange over the 10year period between 2005- 2014. Results from Panel data techniques in the form of Pooled Ordinary Least Squares (POLS), Fixed Effects Panel Data Model (FEM) and Random Effects Panel Data Model (RE M) show that an increase in the equity portion of total debt-equity ratio (TDER) has a significant positive effect on return on equity (ROE). The study thus recommended that non-financial firms should increase the equity portion of their capital structure to enhance firms' financial performance.

Cuong and Canh (2012) studied a sample of 92 firms which comprise of companies listed on two of Vietnam's stock exchange markets from 2005 - 2010. Employing panel threshold regression model this study tested for the panel threshold effect of capital structure on firm value. Authors realized that a debt ratio of $59.27 \%$ is optimal, at which point debt ratio (DR) a proxy of leverage impacted positively on ROE a proxy for firm value.

The premise of all works which have been reviewed up to this point is the linearity assumption which does not consider the existence of an optimal level of capital structure. The optimal capital structure itself presupposes that the relationship between financial leverage and firm value is concave such that after certain maxima, the firm operates a suboptimal level of capital structure where financial leverage contributes only negatively to firm value.

As such Jaisinghani and Kanjilal (2017) examined the impact of capital structure on firm performance in the manufacturing sector of the Indian Stock Market using data of covering the 10-year period between 2005-2014. The study which deployed the Hansen (1999) Panel threshold regression methodology to determine the differentially impact of various levels of leverage on the profitability of firms given their separate sizes. The sample studies comprise of 1194 publicly traded manufacturing firms in India. The study found that firms which exceed the threshold of 148 million rupees are positively impacted by the use of debt in their capital structure.

Muritala (2018) also investigated relationship between the capital structure of ten Nigerian firms and operational firm performance, upon the presumption that it is a linear relationship. With the aid of secondary data 
which covered a five-year period, the results from Panel Least Square (PLS) confirmed that asset turnover, size, firm's age and firm's asset tangibility are positively related to firm's performance

Toraman, Kihc and Reis (2013) investigated the relationship between the capital structure of twenty-eight manufacturing firm in Turkey and their financial performance, over the period between 2005 and 2011. Short-term liabilities to total assets(STA) and long-term liabilities to total assets(LTA), and total debt-to-equity (TDE) were used as measurements of the capital structure, while return on assets (ROA) was used to denote firm performance. The authors utilized a multiple linear regression model and concluded that overall the negative relationship between capital structure and firm performance was negatively significant, while there was no relationship found between the debt-to-equity ratio and return on assets.

Akani \& Kenn-Ndubuisi (2017) studied forty listed companies quoted on the Nigerian Stock Exchange (NSE) while determining the effect of capital structure and board structure on firm performance over the 9-year period between from 2008 to 2016. The study employed the Vector auto regression (VAR) technique on and findings showed that there exists a significant negative causal relationship between Debt to Equity Ratio (as a proxy of capital structure) and ROA (as a measure firm performance).

Khan (2012) investigated the causal relationship between leverage and the performance of 36 companies quoted on the Karachi Stock Exchange (KSE) over the seven-year period between 2003-2009. The study adopted the Pooled Ordinary Least Square regression technique to estimate the parameters. In this work, Khan 2012 utilized both Total debt to Asset ratio (TDTA) and short term debt to total assets (STDT) as proxies of financial leverage because the engineering sector of Pakistan relies heavily on short term debts which affect the performance of the firm. The results reveal show that a negative and statistically significant relationship exists between the 2 measures of capital structure and the Tobin's Q.

Cheng and Tzeng (2011) collected data from 645 companies listed in the Taiwan Securities Exchange (TSE) from 2000-2009. Applying the Generalized Method of Moment (GMM) Model to determine the effect of leverage on firm values and other related variables on firm value, the research found that the values of leveraged firm are greater than that of an unleveraged firm where the risk of bankruptcy is not considered.

Ruan, Tian, and Ma (2011) employed the three stage least square estimation technique to analyze secondary data obtained on 197 privately owned Chinese firms and found that the ratio of total debt to total assets negatively impacts firm value and that firm value also determined the leverage thus identifying an endogeneity or two-way causality between the two variables.

Onaolapo and Kajola (2010) studied the non-financial listed firms on the Nigerian Stock Exchange and found that leverage have a significantly negative relation with performance. Due to agency conflicts between various stakeholders, firms have employed high leverage levels which have negatively affected the performance of the firm.

San and Heng (2011) also studied the relationship between capital structure and the performance of the firm in the Malaysian construction industry especially in the wake of financial crises of 2007-2008 which had a severe impact on many economies of the world including Malaysia. They found that financial leverage had no major impact on the performance of construction industry the industry usually employs large non-current liabilities to prosecute its ongoing large scale development work.

Chadha and Sharma (2015) studied the impact of financial leverage on firm financial performance, in the case of 422 Indian manufacturing companies quoted on Bombay Stock Exchange (BSE). Secondary data for the period of study which was the 10 years from 2004-2013 was used to analyze the leverage effect on Return on Asset, Return on Equity and Tobin's Q as three separate proxies of the firms' financial performances. It was found that financial leverage has no significant impact on two financial performance parameters of the firms namely return on asset and Tobin's Q. Chadha et al. (2015) introduce certain relevant variables such as asset turnover, size of the company, age, number years of existence as well as other significant drivers of a firm's financial performance in the Indian manufacturing sector.

Similarly, Abor and Bokpin (2010) in their study of the effect of a number of variables on dividend payout in the case of 34 firms in Ghana Stock Exchange over the 17-year period between 1990 and 2006, estimated a fixed effects panel model and found out that financial leverage has an insignificant effect on dividend payout.

Rizqia and Sumiati (2013) using a sample of manufacturing companies quoted on Indonesian Stock Exchange studied the effect of managerial ownership, financial leverage, profitability and firm size, on firm value over the 6- year period between 2006-2011. The findings showed that financial leverage, profitability, and firm size has no significant effect on dividend policy.

\subsection{Methodology}

This study adopts the panel data research design with the objective of determining the existence and significance of a causal relationship between the ratio of long term debt to equity (a proxy of financial leverage) and Tobin's $\mathrm{Q}$ (a proxy of firm value). Secondary data was collected on the Assets, Leverage, and Return on Asset of 18 quoted firms over the 5-year period between 2014-2018. The data for the study were obtained from the annual reports and 
financial statements of the companies, which were selected based on the convenience non-random sampling technique.

To address Hypothesis One of this study the degree of causality between the ratio of long term debt to equity (as a proxy of financial leverage) and Tobin's Q (a proxy of firm value) would be ascertained by estimating the coefficient of a Random Effect Panel Data Model, Pooled Ordinary Least Squares Model and Fixed Effect Panel Data Models which include: The Natural Logarithm of Total Asset, Return On Asset, and Age of firm as three mediating variables. In panel data analysis, there is a general problem of determining which model or estimation techniques is most appropriate and in effect which results are most reliable.

There are three option basically serving different purposes namely: Pooled Ordinary Least Squares(POLS) or Panel Least Squares (which operates assuming homogeneity among the subject units and little or no change arising from time differences). The pooled regression model assumes all firms to be homogenous, the intercept as well as the slope coefficients are the same for all of them and there is no impact of time on the dependent variables of our study. The Fixed Effect Panel Data Model (FEM) which is also known as the Least Squares Dummy Variable assumes that there are differences across time and subject units. The Random effect model (REM) on the other hand assumes intercept of a particular firm as being a random selection from a large population which varies non-systematically with a constant mean value.

To determine which model to utilize the Hausman test is conducted. Following Pandey and Sahu (2017), the decision of whether to adopt the results from the Fixed Effect Panel Data Model(FEM) or the Random Effect Panel Data Model(REM) depends whether the changes in the coefficients are systematic or not.

H0: Difference in coefficient not systematic

If the $\mathrm{p}$ value is less than 0.005 reject null hypothesis, and so apply Fixed Effect Panel Data Model rather than the Random Effect Panel Data Model

Table 1: Hausman Test

\begin{tabular}{|l|c|c|l|l|}
\hline & Newey & Reg & Difference & S.E \\
\hline Log LVR & -0.3517284 & -0.3467534 & -0.004975 & 0.08696 \\
\hline Log ASS & -0.3070312 & -0.2977616 & -0.009269 & 0.3863525 \\
\hline Log ROA & 0.7301902 & 0.718613 & 0.0118288 & 0.2566317 \\
\hline Log AGE & -0.1939714 & -0.2072561 & 0.0132848 & 0.1876147 \\
\cline { 1 - 2 } Chi2 & 0.01 & & & \\
\cline { 1 - 2 } Prob $>$ chi $^{2}$ & 1.0000 & & & \\
\cline { 1 - 3 } & & & & \\
\cline { 1 - 2 } & & & &
\end{tabular}

Source: Researchers Computation (Using Stata 14.2)

Since Prob $\left(\mathrm{chi}^{2}\right)>0.5$, we fail to reject null hypothesis and choose therefore random effect panel model over the fixed effect panel model.

Regression Model Specification

This work will thus adopt both the Random Effect Panel Data Estimation Technique (REM) and the Pooled Ordinary Least Squares (POLS) estimation techniques to determine the values of the parameters of the firm value model which has the Tobin's Q (a proxy of firm value) as the dependent variable and the primary explanatory variable being Leverage. Total Asset, ROA, AGE, were include within the model as mediating variable, in line with existing literature such as Li \& Hwang (2011) the variables are imputed into the model after their logarithmic transformations are obtained this is so as to remove the effect of outliers.

$$
\log (\text { Tobin's Q) }=f(L L V R, L A S S, L R O A, L A G E)
$$

When stated in the form of the generalized model for panel data:

$$
\log \mathrm{Q}_{\mathrm{i}, \mathrm{t}}=\alpha+\beta \mathrm{LLVR}_{\mathrm{i}, \mathrm{t}}+\delta \mathrm{LASS}_{\mathrm{i}, \mathrm{t}}+\phi \mathrm{LROA}_{\mathrm{i}, \mathrm{t}}+\gamma \mathrm{LAGE}_{\mathrm{i}, \mathrm{t}}+\mu_{\mathrm{i}, \mathrm{t}}
$$

Table 2: Description of Variables and Parameters

\begin{tabular}{|l|l|l|}
\hline Variables & Interpretation & Purpose \\
\hline Log $\mathrm{Q}_{\mathrm{i}, \mathrm{t}}$ & Natural log of Tobin's Q & Measure of firm value \\
\hline LLVR $_{\mathrm{i}, \mathrm{t}}$ & $\begin{array}{l}\text { Natural log of the Ratio of long term debt } \\
\text { to total equity }\end{array}$ & Measure of financial leverage \\
\hline LASS $_{\mathrm{i}, \mathrm{t}}$ & Natural log of Total Asset & Size of the company \\
\hline LROA $_{\mathrm{i}, \mathrm{t}}$ & Natural log of Returns on Asset & Measure of current profitability of the firm \\
\hline LAGE $_{\mathrm{i}, \mathrm{t}}$ & Natural log of the Age of the Company & Number of years company has been operating \\
\cline { 1 - 2 } $\boldsymbol{\mu}_{\mathrm{i}, \mathrm{t}}$ & Error term & $\begin{array}{l}\text { Measure of variation in the dependent variable } \\
\text { due to unobserved variables }\end{array}$ \\
\cline { 1 - 2 } $\mathbf{A}$ & Constant & \\
\hline $\boldsymbol{\beta}, \boldsymbol{\delta}, \boldsymbol{\phi}, \boldsymbol{\gamma}$ & Parameters of the Model & \\
\hline
\end{tabular}

Correlation

To address Hypothesis Two of this study, the correlation coefficients of the variables would be computed and the levels of significance would also be ascertained, using the pairwise correlation matrix. 
The a-priori expectation of two significantly correlated constructs is a correlation coefficient of $(\mathrm{R})>0.5$, with a P-value that is less than $5 \%$

Test of significance: The estimates obtained under the regression and correlation analyses would be tested for statistical significance using the P-Values. Statistical significance will be determined at 1\%, 5\% and 10\% levels

\subsection{Results}

4.1 Descriptive Statistics

Table 3: Summary Statistics

\begin{tabular}{|c|c|c|c|c|c|}
\hline Variable & Obs & Mean & Std. Dev. & Min & Max \\
\hline Q & 83 & .855996 & 1.425087 & .0005456 & 8.401433 \\
\hline LVR & 83 & .43316 & .847701 & -2.594 & 3.374 \\
\hline ATASS & 83 & $1,110,000,000$ & $3,340,000,000$ & $565,000,000$ & $1,720,000,000,000$ \\
\hline ROA & 83 & 0842106 & .1729353 & -.873 & .866 \\
\hline AGE & 83 & 40.06024 & 28.38599 & 1 & 121 \\
\hline
\end{tabular}

Source: Researcher's Compilation

\subsection{Regression Results}

Hypothesis One: Financial leverage has no significant effect on firm value

Table 4: Regression Results (Using REM, POLS and FEM)

Source: Researcher's Computation

\begin{tabular}{|c|c|c|c|c|c|c|}
\hline & \multicolumn{2}{|c|}{ FIXED EFFECT MODEL } & \multicolumn{2}{|c|}{$\begin{array}{l}\text { POOLED ORDINARY } \\
\text { LEAST SQUARE MODEL }\end{array}$} & \multicolumn{2}{|c|}{ RANDOM EFFECT MODEL } \\
\hline $\log (\mathrm{Q})$ & Coefficient & P Value & Coefficient & P-Value & Coefficient & P-Value \\
\hline LLVR & $\begin{array}{c}-0.3517284 * * \\
(0.1520932)\end{array}$ & 0.024 & $\begin{array}{c}-0.213441 * * * \\
(0.050517)\end{array}$ & 0.0000 & $\begin{array}{r}-0.21344 * * * \\
(0.050812)\end{array}$ & 0.0000 \\
\hline LASS & $\begin{array}{l}-0.7921016 \\
(0.4829593)\end{array}$ & 0.527 & $\begin{array}{c}0.230635^{* *} \\
(0.133961)\end{array}$ & 0.0860 & $\begin{array}{c}0.23063 * \\
(0.134744)\end{array}$ & 0.0879 \\
\hline LROA & $\begin{array}{r}0.7301902 * * \\
(0.3513842) \\
\end{array}$ & 0.042 & $\begin{array}{l}0.500021 * * * \\
(0.098158)\end{array}$ & 0.0000 & $\begin{array}{c}0.50002 * * * \\
(0.098732)\end{array}$ & 0.0000 \\
\hline LAGE & $\begin{array}{c}-0.193971 \\
(0.3227887)\end{array}$ & 0.550 & $\begin{array}{c}-0.516929 * * * \\
(0.110336)\end{array}$ & 0.0000 & $\begin{array}{r}-0.51692 * * * \\
(0.110981)\end{array}$ & 0.0000 \\
\hline $\mathrm{R}^{2}$ & 0.1930 & & 0.156065 & & 0.156065 & \\
\hline $\operatorname{Adj} R^{2}$ & 0.0871 & & 0.146280 & & 0.146280 & \\
\hline $\operatorname{Prob}(\mathrm{F})$ & 0.0899 & & 0.0000 & & 0.000000 & \\
\hline
\end{tabular}

4.3 Correlation Results

Hypothesis Two: There is no significant linear relationship between financial leverage and Tobin's $Q$ Table 5: Correlation Matrix

\begin{tabular}{|c|c|c|c|c|c|}
\hline & Q & LVR & ASS & ROA & AGE \\
\hline Q & 1 & & & & \\
\hline LVR & -0.0296 & 1 & & & \\
\hline ASS & $0.2759 * *$ & -0.0822 & 1 & & \\
& $(0.0116)$ & & & & \\
\hline ROA & 0.1397 & $-0.2477 * *$ & 0.1689 & & 1 \\
& & $(0.0248)$ & & & \\
\hline AGE & -0.0205 & $-0.2066^{*}$ & $-0.0162 * * *$ & 0.0375 & \\
& & $(0.0626)$ & $(0.0001)$ & & \\
\hline
\end{tabular}

Source: Researcher's Computation

\subsection{Discussions}

Table 3. above shows that the mean of firm value (Tobin's Q) of the 18 companies is 0.855 which implies that on average the firms sampled have a higher book value than the market value. If the market value reflects full information about the future streams of earnings of the firms, it can be deduced that the while the mean level of financial leverage is 0.43316 , this means that on average the firms sampled have a debt to equity ratio of $43.316 \%$.

As for the Total Assets ATASS, which measures companies' size, the mean size of the 18 firms in terms of assets is $\mathrm{N} 1,110,000,000$. The average Return on Asset of the firms is 0.0842 this implies that on average the firms make $8.42 \%$ returns on amount invested on assets. The mean age of the sampled companies is 40 years. The variable with the highest variance within the distribution is the Total Asset, while the variable with the most 
minimal variation is Return on Asset (0.1729).

Table 4 shows that under the random effect model, the coefficient estimated for leverage (LLVR) is -0.021344 which is negative but statistically significant at $1 \%$ significance level. Similarly, the parameter estimates of the three mediating regressors-LASS, LROA, LAGE are $0.23063,-0.51692$ and 0.50002 respectively, three of which are statistically significant at $1 \%$ level of significance while the fourth is significant at $10 \%$ level of significance.

The result under the POLS is quite similar to the result obtained under the REM, as the parameter estimate for leverage (LLVR) is also -0.021344 which is negative but statistically significant at $1 \%$ significance level. Similarly, the parameter estimates of the three mediating regressors-LASS, LROA, LAGE are 0.230635 , 0.500021 and $-0.5 \mathrm{I} 6929$ respectively, all of which are statistically significant at $10 \%$ level of significance.

The output obtained from the FEM has slight differences, as the parameter estimate for leverage (LLVR) is -0.35127 which is much larger but less statistically significant with a P-Value of 0.024 it is only statistically significant at 5\% significance level. Similarly, the parameter estimate of LAGE is not statistically significant, although all other variables are statistically significant at $10 \%$ level of significance.

This study adopts the result obtained from the REM, being the most reliable given that differences in the variables have proven to be random and unsystematic. To this end, it can be deduced that a $1 \%$ increase in financial leverage will bring about a $0.21344 \%$ reduction in the overall firm value, while $1 \%$ increase in both LASS and LROA will result in $0.23 \%$ increase and $0.516 \%$ decrease in firm value respectively. Additionally, the results show that the average firm value drops by $1.25 \%$ annually

As such we reject the null hypothesis that there is no significant causal relationship between firm value and financial leverage. The results are in line with the findings of Ifechi, Kenn-Ndubuisi and Chijioke Joel (2019), Chadha and Sharma (2015) as well as Abdul \& Badmus (2017). The F statistic which is 0.0000 shows that the Model is statistically significant

Table 5 above shows the result of the pairwise correlational matrix which depicts the degree of the correlational relationship between all the variables under study. There exists a negative and weak relationship between dependent variable (firm value) and the primary explanatory variable (financial leverage) $\mathrm{r}=-0.1294$, however, since the $p$ value is 0.7919 which is greater than .05 hence, the relationship is considered to be statistically insignificant.

The coefficient of correlation between the total value of assets (ASS) and the Tobin's Q is given as 0.2759 which shows that the relationship is a weak and positive one, this is however statistically significant $(0.0116)$ at $5 \%$ level of significance. The table 5 also shows that financial Leverage (LVR) and Measure of firm profitability(ROA) move in opposite directions, the coefficient of correlation which is estimated at $-0.2477(0.0248)$ is statistically significant at $5 \%$ significance level.

Hence, we fail to reject the null hypothesis that there is no significant linear relationship between financial leverage and firm value.

\subsection{Conclusion}

5.1 Summary of Findings

The Trade-off theory of capital structure holds that within a certain range higher leverage results in higher firm value beyond which more debts brings about higher default risk and lower firm value. Hence, like previous studies like Jaisinghani et al. (2017) this work sought to determine whether the firms on the stock exchange had an optimal capital structure or not. The Hausman test was conducted in order to determine which of the three alternative empirical models (i.e. POLS, REM and FEM) would generate the most reliable results and the result showed that the Random Effect Panel Model was the better estimation technique given that the differences within the coefficients are not systematic.

The level of financial leverage was surrogated by long term debt to equity ratio, while firm value was measured by the Tobin's q. The model also included variables such as the Total Asset, Return on Asset and the Age of the firms. Data obtained from the annual reports of the firms were utilized in determining the causal and correlational relationships between the dependent variable and the regressors.

The results obtained suggest that there exists a negative causal relationship that is significant between financial leverage and firm value, where a $1 \%$ increase in financial leverage will bring about a $0.21344 \%$ reduction in the value of the firm, as for the impact of the other regressors, it was discovered that the size of the firm measured by assets $1 \%$ increase in both LASS and LROA will result in $0.23 \%$ increase and $0.516 \%$ decrease in firm value respectively. Similarly, the results show that the average firm value drops by $1.25 \%$ annually.

Therefore, we reject the null hypothesis that there is no significant causal relationship between firm value and financial leverage. The results are in line with the findings of Ifechi, Kenn-Ndubuisi and Joel (2019), Chadha and Sharma (2015) as well as Abdul \& Badmus (2017) but contrarian, to the findings of Jaisinghani and Kanjilal (2017) and Muritala (2018). 


\subsection{Recommendations}

The Management of these companies are therefore advised to take less long term debt and instead such firms should consider equity as an alternative. The firm can consider issuing more equity to reduce the level of financial leverage and thereby attain the optimal capital structure. Furthermore, the value of financial leverage has proven to be a weak predictor of firm value hence the management should not rely on the levels of financial leverage to predict future firm value. Also the firm should prioritize the acquisition of tangible assets has it has proven to have a significant positive effect on firm value just as it may be necessary for the firms to complement increase in average total assets with steady increase in Net income in order to achieve much more favourable Return on Asset(ROA).

Although this study has considered firms in each and every segment of the stock market, further studies may consider the use of a larger sample and a random selection method particularly the stratified sampling technique which will divide the firms based on their level of capitalization which is mid-capitalization, low-capitalization and high-capitalization companies so as to determine the actual value of optimal capital structure for each of the three classes. Finally, this study has used a five-year data between 2014-2018, a longer time period can be studied in the future.

\section{REFERENCES}

Abor, J. and Bokpin, G.A., 2010. Investment opportunities, corporate finance, and dividend payout policy. Studies in economics and finance. https://doi.org/10.1108/10867371011060018

Abubakar, A., 2016. Financial leverage and firms' performance: A study of quoted companies in the Nigerian stock exchange. In Conference Paper.

Akani, H.W. and Ifechi, K.N.J., 2017. Effects of capital structure and board structure on corporate performance of selected firms in Nigeria. Indian Journal of Finance and Banking, 1(2), pp.1-16.

Arosa, C.M.V., Richie, N. and Schuhmann, P.W., 2014. The impact of culture on market timing in capital structure choices. Research in International Business and Finance, 31, pp.178-192.. https://doi.org/10.1016/j.ribaf.2013.06.007

Brainard, W.C. and Tobin, J., 1968. Econometric models: their problems and usefulness. Pitfalls in financial model building. American Economic Review, 58(2), pp.99-122.

Central Bank of Nigeria, 2019. Guidelines on accessing the CBN standing deposit facility. (FMD/DIR/CON/OGC/12/019) Abuja: Nigeria. https://www.cbn.gov.ng

Chadha, S., \& Sharma, A. K., 2015. Capital structure and firm performance: Empirical evidence from India. Vision, 19(4), pp.295-302. https://doi.org/10.1177\%2F0972262915610852

Cheng, M.C. and Tzeng, Z.C., 2011. How does ownership structure affect capital structure and firms performance. Evidence from Taiwan, "Global Review of Accounting and Finance, 2(2).

Cuong, N.T. and Canh, N.T., 2012. The factors affecting capital structure for each group of enterprises in each debt ratio threshold: evidence from Vietnam's Seafood Processing Enterprises. International Research Journal of Finance and Economics, 94, pp.23-37.

DARE, F.D. and Olorunfemi, S., 2010. Capital structure and corporate performance in Nigeria petroleum industry: panel data analysis.

Demirgüç-Kunt, A. and Maksimovic, V., 1999. Institutions, financial markets, and firms' choice of debt maturity. The World Bank. https://doi.org/10.1596/1813-9450-1686

Ebiringa, O.T. and Ezeji, E.C., 2012. Analysis of effect of financing leverage on bank performance: Evidence from Nigeria. Journal of Public Administration and Governance, 2(4), pp.178-187. https://doi.org/10.5296/jpag.v2i4.3036

Ebiringa, O.T. and Ezeji, E.C., 2012. Analysis of effect of financing leverage on bank performance: Evidence from Nigeria. Journal of Public Administration and Governance, 2(4), pp.178-187.

Ferri, M. G., \& Jones, W. H., 1979. Determinants of financial structure: A new methodological approach. The Journal of Finance, 34(3), pp.631-644. https://doi.org/10.1111/j.1540-6261.1979.tb02130.x

Fisher, F.M. and McGowan, J.J., 1983. On the misuse of accounting rates of return to infer monopoly profits. The American Economic Review, 73(1), pp.82-97.

Franks, J.R. and Pringle, J.J., 1982. Debt financing, corporate financial intermediaries and firm valuation. The Journal of Finance, 37(3), pp.751-761. https://doi.org/10.1111/j.1540-6261.1982.tb02221.x

Ganguli, S.K. and Agrawal, S., 2009. Ownership Structure and Firm Performance: An Empirical Study on Listed Mid-Cap Indian Companies. IUP Journal of Applied Finance, 15(12).

Hamada, R.S., 1969. Portfolio analysis, market equilibrium and corporation finance. The Journal of Finance, 24(1), pp.13-31. https://doi.org/10.1111/j.1540-6261.1969.tb00339.x

Hansen, B.E., 1999. Threshold effects in non-dynamic panels: Estimation, testing, and inference. Journal of econometrics, 93(2), pp.345-368. https://doi.org/10.1016/S0304-4076(99)00025-1

Hart, O., and Moore J. 1995. Debt and Seniority: An Analysis of the Role of Hard Claims in Constraining 
Management." American Economic Review 85, 567-585. https://doi.org/10.3386/w4886

Isola, W.A. and Akanni, L.O., 2015. Corporate financial structure of nonfinancial quoted companies in Nigeria. Managing Global Transitions, 13(3), p.267.

Jaisinghani, D. and Kanjilal, K., 2017. Non-linear dynamics of size, capital structure and profitability: Empirical evidence from Indian manufacturing sector. Asia Pacific Management Review, 22(3), pp.159165.https://doi.org/10.1016/j.apmrv.2016.12.003

Jeleel, A. and Olayiwola, B., 2017. Effect of leverage on firm performance in Nigeria: A case of listed chemicals and paints firms in Nigeria. Global Journal of Management And Business Research.

Jensen, M. C., \& Meckling, W. H. 1979. Theory of the firm: Managerial behavior, agency costs and ownership structure. In Economics social institutions (pp.163-231). Springer, Dordrecht.

John-Akamelu, R.C., Iyidiobi, F.C. and Ezejiofor, A.R., 2017. Leverage and financial performance: Evidence from Nigerian food production firms. European Journal of Research and Reflection in Management Sciences, 5 (4), 1,11 .

Kenn-Ndubuisi, J.I. and Nweke, C.J., 2019. Financial Leverage and Firm Financial Performance in Nigeria: A Panel Data Analysis Approach. Global Journal of Management And Business Research.

Kester, W.C., 1986. Capital and ownership structure: A comparison of United States and Japanese manufacturing corporations. Financial management, pp.5-16.https://doi.org/10.2307/3665273

Khan, A.G., 2012. The relationship of capital structure decisions with firm performance: A study of the engineering sector of Pakistan. International Journal of Accounting and Financial Reporting, 2(1), pp.245-262. https://doi.org/10.5296/ijafr.v2i1.1825

Kim, E.H., 1978. A mean-variance theory of optimal capital structure and corporate debt capacity. The journal of Finance, 33(1), pp.45-63. https://doi.org/10.1111/j.1540-6261.1978.tb03388.x

Kyereboah-Coleman, A., 2007. The impact of capital structure on the performance of microfinance institutions. The Journal of Risk Finance. https://doi.org/10.1108/15265940710721082

Lee, Y., Su, S. C., \& Lin, W. C. 2012. Capital structure timing in markets with different characteristics. The International Journal of Business and Finance Research, 6(3), pp53-66.

Li, M. Y. L., \& Hwang, N. C. R. 2011. Effects of firm size, financial leverage and R\&D expenditures on firm earnings: An analysis using quantile regression approach. Abacus 47(2), pp182-204. https://doi.org/10.1111/j.1467-6281.2011.00338.x

Miller, M. H. 1977. Debt and taxes. the Journal of Finance, 32(2), pp261-275. https://doi.org/10.1111/j.15406261.1977.tb03267.x

Mishkin, F., 2007. Money, banking and financial markets. New Horizons, Paris, France.

Modigliani, F. and Miller, M. H. 1958. The Cost of Capital, Corporate Finance and the Theory of Investment. American Economic Review, 48, pp. 261-97.

Modigliani, F. and Miller, M. H. 1963. Corporate Income Taxes and the Cost of Capital: A Correction. American Economic Review, 53, pp433-43.

Miller, M.H. and Modigliani, F., 1967. Some Estimates of the Cost of Capital to the Electric Utility Industry, 19541957: Reply. The American Economic Review, 57(5), pp.1288-1300.

Modigliani, F. and Miller, M.H., 1969. Reply to Heins and Sprenkle. The American Economic Review, 59(4), pp.592-595.

Muritala, T.A., 2012. An empirical analysis of capital structure on firms' performance in Nigeria. International Journal of Advances in Management and Economics, 1(5), pp.116-124.

Myers, S.C., 1977. Determinants of corporate borrowing. Journal of financial economics, 5(2), pp.147-175. https://doi.org/10.1016/0304-405X(77)90015-0

Myers, S.C., 1984. The capital structure puzzle. The journal of finance, 39(3), pp.574-592.

doi: $10.2307 / 2327916$

Obradovich, J. and Gill, A., 2013. The impact of corporate governance and financial leverage on the value of American firms.

Onaolapo, A.A. and Kajola, S.O., 2010. Capital structure and firm performance: Evidence from Nigeria. European Journal of Economics, Finance and Administrative Sciences, 25(1), pp.70-82.

Oteh, A. (2010). A Roadmap for Transforming the Nigerian Capital Markets, Press Briefing, Securities and Exchange Commission Media Center.

Pandey, K.D. and Sahu, T.N., 2017. An empirical analysis on capital structure, ownership structure and firm performance: Evidence from India. Indian Journal of Commerce and Management Studies, 8(2), pp.63. http://doi.org/10.18843/ijcms/v8i2/09

Rajan, R.G. and Zingales, L., 1995. What do we know about capital structure? Some evidence from international data. The journal of Finance, 50(5), pp.1421-1460. https://doi.org/10.1111/j.1540-6261.1995.tb05184.x

Rizqia, D.A. and Sumiati, S.A., 2013. Effect of managerial ownership, financial leverage, profitability, firm size, and investment opportunity on dividend policy and firm value. Research Journal of Finance and Accounting, 
4(11), pp.120-130.

Robichek, A.A. and Myers, S.C., 1966. Problems in the theory of optimal capital structure. Journal of Financial and Quantitative Analysis, 1(2), pp.1-35.

Ruan, W., Tian, G. and Ma, S., 2011. Managerial ownership, capital structure and firm value: Evidence from China's civilian-run firms. Australasian Accounting, Business and Finance Journal, 5(3), pp.73-92. http://ro.uow.edu.au/aabfj/vol5/iss3/6

Salawu, R.O. and Awolowo, O., 2009. The effect of capital structure on profitability: An empirical analysis of listed firms in Nigeria. The International Journal of Business and Finance Research, 3(2), pp.121-129.

San, O.T. and Heng, T.B., 2011. Capital structure and corporate performance of Malaysian construction sector. International Journal of Humanities and Social Science, 1(2), pp.28-36.

Schall, L.D., 1972. Asset valuation, firm investment, and firm diversification. Journal of Business, pp.11-28.. https://doi.org/10.1086/295422

Scott Jr, J.H., 1976. A theory of optimal capital structure. The Bell Journal of Economics, pp.33-54.

SEC Office of Investor Education and Advocacy (2015). What are corporate bonds? SEC Investor Bulletin, 149 (6-13)

Kester, W.C., 1986. Capital and ownership structure: A comparison of United States and Japanese manufacturing corporations. Financial management, pp.5-16. 